\title{
REVERSE SHOTS: INDIGENOUS FILM AND MEDIA IN AN INTERNATIONAL CONTEXT Pearson, W. G., \& Knabe, S. (Eds.), 2014, Waterloo, Canada, Wilfrid Laurier University Press
}

\section{Paula Sequeiros}

Universidade de Coimbra, CES - Centro de Estudos Sociais. Colégio de S. Jerónimo, Largo D. Dinis, Apartado 3087, 3000-995 Coimbra, Portugal. Email: paulasequeiros@ces.uc.pt

Num trocadilho entre o disparo da arma de fogo e o da câmara de filmagem, ${ }^{1}$ Reverse Shots é uma coletânea produzida para questionar o que significa hoje "Globalizar o cinema e os meios de comunicação indígenas" 2 e avançar possíveis respostas. O livro resulta da conferência Indigenous film and media in an international context, da Universidade Wilfrid Laurier no Canadá, e do trabalho das editoras científicas Wendey Gay Pearson e Susan Knabe.

Questões centrais na representação das vidas de populações e pessoas indígenas são elencadas a partir de casos de produção artística e jornalística, focando especialmente o audiovisual e referindo a escrita e a oralidade literárias.

Em primeiro lugar, creio ser esta coletânea uma boa aposta e exemplo do resultado da recoleção de textos sobre casos particulares que, criticamente editados, ampliam o seu sentido singular e proporcionam reflexão teórica e compreensão acrescida, neste caso sobre o que é o colonialismo e o pós-colonialismo. Questão tão mais relevante quanto a ambivalência e o preconceito naturalizado assomam frequentemente nas apreciações quotidianas das realidades pós-coloniais e do racismo: a confrontação com o olhar do Outro, já não objeto mas autor/a das suas próprias imagens, revela-se indispensável. Até porque "[...] o que é evidente para os próprios povos indígenas e seus aliados pode não ser manifestamente visível no discurso populista, ou pode simplesmente mostrar-se impopular com populações que têm ainda de aceitar o seu passado racista, quanto mais reconhecer um presente racista" (p.5). Daí a necessidade do contracampo - reverse shot - , de tomar imagens "a partir da posição de que a audiência estava previamente a olhar" (p. 16).

No livro congregaram-se os trabalhos de cientistas e académicos, artistas e cultores do filme e da dança - em papéis por vezes sobrepostos - de várias proveniências, como Canadá, EUA, Austrália, Aotearoa/Nova Zelândia, México, Noruega.

Um dos grandes desafios subjacente à coletânea consistiu em analisar essas produções artísticas dos períodos coloniais e posteriores à colonização através do olhar cruzado e do diálogo entre as próprias e diferentes culturas indígenas.

Por entre a diversidade dos quinze trabalhos coligidos, alguns enfatizam as preocupações de ordem metodológica interligadas com a ética (apropriação cultural, reconhecimento da diversidade, tratamento respeitoso, uso do humor, relações 
participativas na pesquisa). Destaco o capítulo 10 autorado por Stephen Foster e Mike Evans ("The Prince George métis elders documentary project") que se apoiam em Paulo Freire, Orlando Fals Borda e Stuart Hall. Destaco ainda o capítulo 11 de Ute Lischke ("Whacking the indigenous funny bone") que refere abundantemente Drew Hayden Taylor e a teoria do conhecimento situado - associada a Sandra Harding e a Donna Haraway na introdução assinada pelas organizadoras da coletânea.

Note-se que a seç̧ão "Descolonizando histórias", capítulos 2 a 6, marca o debate teórico pelo destaque particular à desconstrução de duas modalidades correntes de confinamento operado pelo pensamento colonial: a do indígena como aquele "que continua no passado" e a redução da atual condição indígena a um diagnóstico cumulativo de formas de mal-estar social.

Logo na introdução, as editoras Wendey Gay Pearson e Susan Knabe propõem uma interessante análise de tropos presentes na linguagem fílmica e mediática que designam como: taxidermia (busca de uma imagem autêntica do indígena, mais verdadeira do que a do original postulado, fazendo-o "parecer" vivo); zombies (sátira ao rótulo em extinção, aposto a culturas e povos indígenas, apesar de registarem crescimentos superiores aos das etnias colonizadoras); resistência (contra-cultura face aos estereótipos de Hollywood, ao cinema dominante e nacional em que só ocasional e secundariamente participam indígenas); reapropriação (re-historiografia do cinema a partir de representações e figurações dos próprios e através da sua autoria).

Epistemologicamente, exige-se que a reapropriação, mudança fundamental, venha marcada pela criação de obras "por, para e sobre" as populações originárias (p. 7-8). Historicamente, sinaliza-se uma produção forte entre o final dos anos 60 e os 70, realizada a par de movimentações pelos direitos indígenas em vários pontos do globo (caso das Primeiras Nações do Canadá, do American Indian Movement, dos protestos em Camberra e das lutas sámis ${ }^{3}$ contra a barragem de Alta/Kautokeino). Vários documentários, de 2000 até ao presente, evocarão ainda essas movimentações.

Os usos do digital no cinema e media indígenas merecem um destaque introdutório, desde os momentos iniciais marcados pela forte intenção de documentar e mostrar, até uma adoção do digital orientada para proporcionar o contacto de populações indígenas entre si, ou outras, mas sob o seu controle. Nestes últimos usos se enquadram o Centro de Trabalho Indigenista de São Paulo, que dá formação no uso de vídeo e distribui câmaras na bacia do Amazonas, e a Isuma.tv, que promove a distribuição em linha junto de produtores indígenas. A título de exemplo, estas estratégias convergiram no filme $A$ arca dos $Z o^{\prime} e ́$, onde se percebe como a liderança Waiwai, povo wajãpi, ${ }^{4}$ usa as imagens para o conhecimento mútuo com os zo'é, povo sem contacto conhecido até aos fins do séc. 20. 
Pearson e Knabe não deixam de enfatizar que, às facilidades potenciais associadas às novas tecnologias, se contrapõem as dificuldades da pobreza relativa, do acesso à formação e da falta de salas para exibição com que as populações indígenas se enfrentam ainda. Estas desigualdades constrangem o aparecimento de novos filmes, num desequilíbrio profundo com a produção dominante, mais notório ainda na falta de obras ficcionais, que requerem mais recursos, levando a que a maior parte se encerre na categoria do documentário.

De entre os trabalhos coligidos seleciono ainda aspetos que considero especialmente importantes, se não pela originalidade, pela contundência da discussão, a qual confere a esta obra relevância e singularidade. É o caso do questionamento da "veracidade" indígena (capítulo 8, por Adam Szymanski e Jenny Fraser) em programas maori para a televisão neozelandesa. Tendo recorrido a estéticas avançadas, supostamente exógenas, esses programas afrontam o estereótipo do zomby, usando a formulação de Pearson e Knabe. É o caso ainda da possibilidade de conjugar especificidade cultural com diversidade artística, mediando visões díspares sobre a vida aborígene e lidando com diferentes públicos (maori e pakeha ${ }^{4}$ ) e suas expectativas, através de códigos cinemáticos paralelos familiares a cada um dos grupos. É o caso também da contestação da antinomia arte (ocidental) e artesanato (indígena). Adicionalmente, Gail Vanstone (capítulo 13) contesta as etiquetas de género - arte séria masculina, artesanato feminino - , algo sem consistência nas culturas das Primeiras Nações. Essas contestações vão ser fundamentadas por Vanstone, a partir de Hands of history de Loretta Todd. Já o recurso ao humor, passando pela ironia, é tratado com detalhe por Tanis MacDonald, partindo do filme Heater, de Terrance Oddette. MacDonald associa a situação de dois sem-abrigo que se tornam amigos - um indígena temporariamente sem casa e um branco doente mental - à flânerie do Norte global, situação apesar de tudo vivida desigualmente. Um último destaque para as referências ao cinema sámi e ao colonialismo escandinavo, invocados em filmes como Ofelas - O guia da montanha, na versão em português e The Kautokeino rebellion de Nils Gaup. O tema do primeiro é a história de um encontro com colonos invasores, o do segundo, a resistência sámi à construção da barragem de Alta. Neles se rompe o silenciamento sobre a cultura sámi, as suas resistências e a repressão colonial. Um dos atos extremos desta consistiu em decapitar dois lideres sámis e manter a custódia dos crânios em território alheio, no Instituto Anatómico em Oslo. Se este desmembramento é tomado por Wendey Gay Pearson (capítulo 6) como sinédoque do processo colonial no Sápmi, as obras de Gaup são tratadas como exemplo do apoio conferido pelo cinema à afirmação da "soberania visual" (p. 168) dos povos. Nesta abordagem, um processo descolonizador exige a revindicação do conhecimento indígena, uma perspetiva histórica 
própria e a opção sobre como se representar na imagem, passando ainda pela apropriação de meios e técnicas atuais não tradicionais.

A coletânea Reverse shots consegue aliar profundas análises dos conteúdos a um rico e criativo questionamento das estéticas e das afirmações identitárias indígenas, sempre dentro dos paradigmas pós-coloniais. Pode ser apreciada por quem se interesse tanto pela produção e análise das imagens em movimento como pelo reconhecimento das culturas indígenas.

Pela contundência e pela analogia com outros contextos, resulta particularmente interessante a proposta de Jo Smith e Sue Abel tendente à superação da "domesticação cultural" - presente, segundo os autores, no "biculturalismo benévolo que incorporou as coisas maori num estado nação de contrário sem cor, sem [contudo] fazer mudanças estruturais nas formas existentes de governação" (capítulo 7, p. 181).

\section{Notas}

1 Por decisão pessoal, a autora do texto escreve segundo o novo acordo ortográfico.

2 Título da introdução assinada pelas editoras.

3 População originária do extremo Norte da Europa, dividida atualmente pelos estados da Noruega, Suécia e Finlândia; até ao regime de Estaline ocupou ainda a península de Kola; o território sámi denomina-se Sápmi, conhecido contudo pelo exónimo Lapónia.

4 Povo indígena da América doSul que reside na zona delimitada pelas bacias dos rios Jari, Oiapoque e Araguari, nos estados brasileiros de Amapá e Pará e na Guiana Francesa.

5 Pessoa neozelandesa com ascendência europeia.

Paula Sequeiros. Universidade de Coimbra, CES - Centro de Estudos Sociais. Colégio de S. Jerónimo, Largo D. Dinis, Apartado 3087, 3000-995 Coimbra, Portugal.

Email: paulasequeiros@ces.uc.pt

Data de submissão: 31/05/2017 | Data de aceitação 22/11/2017 